\title{
Anti-Allergic Inflammatory Effect of and Jeotgal on Human Mast Cell Line (HMC-1)
}

Yu-Jin Ko ${ }^{1}$, Hui-Hun Kim${ }^{1}$, Eun-Jung $\mathrm{Kim}^{1}$, Jin-Yong $\mathrm{Kim}^{1}$, Sang-Dong Kang ${ }^{1}$, Yong-Hwi Son ${ }^{1}$, Sin-Yang Choi ${ }^{2}$, Seong-Kwan Cha ${ }^{2}$, Jong-Won Kim ${ }^{1}$, Jeong-OK Lee ${ }^{1}$ and Chung-Ho Ryu ${ }^{1}$ *

${ }^{1}$ Division of Applied Life Science(BK21 program), Institute of Agriculture and Life Science, Gyeongsang National University. Jinju 660-701, Korea

${ }^{2}$ Korea Food Research Institute, Seongnam 463-420, Korea

Received November 19, 2010/Accepted January 21, 2011

\begin{abstract}
The mast cell is one of the major effector cells in inflammatory reactions and can be found in most tissues throughout the body. Activated mast cells can produce histamine, as well as a wide variety of other inflammatory mediators such as eicosanoids, proteoglycans, proteases, and several pro-inflammatory cytokines, such as tumor necrosis factor (TNF) $-a$, and interleukins (IL-6), IL-8, IL-4, IL-13. In the present study, we isolated two bacterial strains (J80 and G147) from fermented soybean and Jeotgal, and investigated the inhibitory effects of their extracts which were prepared by several pretreatment methods (sonication for $20 \mathrm{~min}$, heating at $100^{\circ} \mathrm{C}$ for $30 \mathrm{~min}$, autoclaving at $121^{\circ} \mathrm{C}$ for 15 min) on the mast cell-mediated inflammatory response. The pretreated bacterial extracts had no cytotoxicity against Human Mast Cell (HMC-1). Among various pretreatments, the extracts treated at 10 $0^{\circ} \mathrm{C}$ showed highest inhibition of histamine release (J80, 28.46\%; G147, 41.14\%). The J80 and G147 extracts treated at $100^{\circ} \mathrm{C}$ resulted in the inhibition of IL-6 secretion by $38.46 \%$ and $56.45 \%$, respectively. The $\mathrm{J} 80$ extract treated at $100^{\circ} \mathrm{C}$ resulted in the inhibition of TNF-a secretion by $66.67 \%$, but G147 extract showed the highest inhibition effect by $41.1 \%$ when treated with sonication. These results suggest that bacterial extracts treated at $100^{\circ} \mathrm{C}$ have a higher level of anti-inflammatory effects than other treatments such as sonication or autoclaving.
\end{abstract}

Key words : Mast cell, cytokine, histamine, anti-inflammatory effect, fermented soybean, Jeotgal

\section{서 론}

알레르기는 피부나 점막, 호흡기 등을 통해 침입하는 외 부물질에 대한 체내의 과민반응으로 인해 나타나는 질병 이다. 이러한 과민반응은 신체의 기능에 여러 가지 이상증 세를 일으키며 자주 재발하거나 만성화되는 것이 특징이 다[1].

과민반응은 4 가지로 분류할 수 있으며 이 중 1 형 과민반응 은 널리 알려져 있는 알레르기 반응으로 $\operatorname{IgE}$ 항체와 비만세포 에 의해 일어난다[1,25,30]. 비만세포는 아토피 피부염, 기관지 천식, 알레르기성 비염과 같은 염증반응에 관련되는 주요 세 포 중 하나[3]로써 $\mathrm{IgE}$ 가 매개하는 면역반응과 관계되어 있으 며, $\mathrm{T}_{\mathrm{H}} 2$ type에 의존적인 면역과민성 반응과 알레르기성 질환 및 특정 선천성 면역반응을 유도하는 것으로 알려져 있다[36]. 특히 외부자극으로부터 활성화된 비만세포는 다양한 protease나 histamine과 같은 혈관확장물질들을 분비하며, 염증 유발물질인 다양한 TNF-a, $\mathbb{L}-6, \mathbb{L L}-8, \mathbb{L}-13$ 과 같은 사이토카

*Corresponding author

Tel : +82-55-772-1905, Fax : +82-55-772-1909

E-mail : ryu@gnu.ac.kr
인의 분비를 자극한다[31].

Histamine은 비만세포의 탈과립에 의해 분비되는 물질 중에서 가장 잘 알려져 있고, 즉시형 과민반응과 관련된 중 요한 인자들 중의 하나이다[22,30]. Histamine은 2 5 $\mathrm{pg} / \mathrm{mast}$ cell 정도로 비만세포 내에 존재하며 기관지 수축, 점액분비 증가, 혈관확장, 혈관투과성 증가 등을 일으킨다 [15]. TNF- $\mathrm{a}$ 는 자가 분비할 뿐만 아니라 $\mathrm{IL}-6, \mathrm{IL}-8$ 과 같은 염증성 cytokine의 유도인자이다[2,4]. IL-6는 T cell, monocytes, macrophage 등에 의해 생성되는 다면발현 염증성 cytokine이며, B cell분화의 유도와 T cell의 성장과 분화 등 의 기능을 가진다. IL-8은 류머티즘과 같은 염증질환에서 많 이 발견되고[3], 호중구, $\mathrm{T}$ 림프구, $\mathrm{B}$ 림프구, 호산구와 같은 염증 관련 세포에 영향을 미친다[24].

염증반응의 치료에는 약물치료가 가장 많이 사용되고 있으 나 약물치료 시 부작용이 커서 사용하는데 상당한 어려움이 있다. 최근 염증반응 억제에 관한 연구로는 발효식품[10], 한약 재[11,17] 그리고 미생물 $[6-9,14,37]$ 등을 이용하여 다양하게 이 루어지고 있다.

장류는 기본적으로 콩을 주로 사용하는 발효식품의 총칭으 로, 장(醬)은 음식의 맛을 내기 위한 조미료로서 우리 음식문화 에서 큰 비중을 차지하고 있다. 최근 식물성 콩 단백질의 건강 
증진 효과 등에 관한 기능성 연구가 활발히 진행되고 있으며 서구인들조차 콩의 유용성에 상당한 관심을 집중하고 있는 실정이다. 자연계의 콩 단백질의 분해와 동시에 효소를 축적 하여 생성된 메주를 이용하는 전통발효식품인 장류에는 간장, 된장, 혼합장 등이 있다[19].

젓갈은 예로부터 우리나라 사람들이 즐겨 먹는 대표적인 전통 수산발효식품 중의 하나로, 단백질, 지방, 무기질의 공급 원으로서 영양학적으로 중요한 식품이다. 젓갈 제조 시 첨가 되는 식염은 부패미생물의 생육을 억제하고 내염성의 발효미 생물이 선택적으로 생장할 수 있도록 조절을 하여 젓갈의 저 장성을 연장시켜주는 중요한 역할을 한다[27].

우리나라의 대표적인 발효식품인 김치 유산균은 균주 동정 및 효능에 대하여 다양하게 연구되고 있으며 특히 유산균의 건강증진 효과는 생균일 때뿐만 아니라 가열살균[13,26,32], 동 결건조 형태[21,28], 유산균 파쇄액[12] 또는 동결건조한 유산 균 파쇄액[5,33] 의 형태로 공급을 하였을때도 건강증진 작용 이 있어 사멸한 이후에도 이 균체 성분이 장으로 흡수되어 생리활성을 가질 것으로 생각되고 있다. 이러한 유산균의 상 태에 따른 효능이 밝혀짐에 따라 유산균을 이용한 단순한 발 효식품의 제조뿐만 아니라 이들 유산균을 편리한 형태로 제조 하여 그 유용성을 여러 식품에 적용하고자 하는 연구가 진행 되고 있다. 그러나 다른 발효식품인 장류나 젓갈에서 분리된 발효 균주의 기능성에 대한 연구는 부족한 실정이다. 이에 본 연구에서는 처리방법(sonication, heating, autoclaving)에 따 른 장류 및 젓갈 유래 균체의 비만세포 매개 항염증 효과를 조사하였다.

\section{재료 및 방법}

\section{분리균주의 동정}

장류 및 젓갈에서 분리한 균주의 정보를 확인하기 위하여 각 균주의16S rRNA sequencing을 Macrogen (Seoul, Korea) 에 의뢰하여 실시하였다.

\section{균주 및 전처리}

본 연구에서 사용한 균주는 젓갈, 장류에서 분리한 균주 (J80, G147)로 한국식품연구원에서 분양받아 실험에 사용하였 다. 각 균주는 $\mathrm{MRS}$ 배지에 $24 \mathrm{hr}$ 동안 배양하여 원심분리(8,000 $\mathrm{rpm}, 10 \mathrm{~min}$ )한 후 PBS로 2회 세척하였다. 세척한 균체를 각각 sonication (20 min), heating $\left(100^{\circ} \mathrm{C}, 30 \mathrm{~min}\right)$, autoclaving $\left(121^{\circ} \mathrm{C}\right.$, $15 \mathrm{~min})$ 하여 원심분리 $(8,000 \mathrm{rpm}, 10 \mathrm{~min})$ 한 다음 상징액을 $0.45 \mu \mathrm{m}$ membrane filter로 filtering한 후 동결 건조하여 실험 에 사용하였다.

\section{$\mathrm{HMC}-1$ 세포 배양}

HMC-1세포(HMC-1, a kind gift from Dr. H.M. Kim at
Kyeonghee Universiry, Seoul, Korea)는 10\% Fetal bovine serum (FBS), $100 \mathrm{U} / \mathrm{ml}$ penicillin과 $100 \mathrm{ug} / \mathrm{ml}$ streptomycin이 함유 된 Isocove's modified Dulbecco's medium (IMDM)를 이용하 여 $37^{\circ} \mathrm{C}, 5 \% \mathrm{CO}_{2}$ 에서 배양하였다.

\section{세포 생존율 측정}

HMC-1세포의 생존율은 3-(4,5-dimethylthiazol-2-yl)-2,5diphenyl-tetrazolium bromide (MTT) assay로 실험하였다 [16]. $\mathrm{HMC}-1$ 세포 $\left(5 \times 10^{5} \mathrm{cell} / \mathrm{ml}\right)$ 에 균주 추출물을 $1 \mathrm{mg} /$ $\mathrm{ml}$ 로 조절하여 $500 \mathrm{ul}$ 배양액에 $5 \mathrm{ul}$ 를 처리하고 $30 \mathrm{~min}$ 간 incuvator에서 반응 후 Phorbol 12-myrostate 13-acetate (PMA)와 calcium ionophore A23187로 8시간 자극하였다. 자극 후 MTT solution $\left(50 \mathrm{ul}\right.$ )를 첨가하여 $37^{\circ} \mathrm{C}$ 에서 overnight하고 dimethyl sulfoxide (DMSO)로 결정을 녹인 후 $540 \mathrm{~nm}$ 에서 흡광도를 측정하였다. 균체 추출물과 자극제를 처리하지 않은 무처리구의 흡광도를 $100 \%$ 로 하여 세포 생 존율을 계산하였다.

\section{Histamine 유리억제율 측정}

세포 배양 상층액 중에 있는 히스타민의 정량은 Shore [34] 의 방법에 따라 에펜돌프 튜브에 배양액 $500 \mathrm{ul}$ 를 넣고 0.1 $\mathrm{N}-\mathrm{HCl} 450 \mathrm{ul} 60 \%$ 과염소산 용액 $50 \mathrm{ml}$ 를 넣고 혼합 후 원심 분리(15,000 rpm, $20 \mathrm{~min}$ )하여 그 상층액 $800 \mathrm{ul}$ 를 $5 \mathrm{~N}-\mathrm{NaOH}$ 용액 $500 \mathrm{ul}$, 증류수 $3 \mathrm{ml}, \mathrm{n}$-butanol $10 \mathrm{ml}$ 및 $\mathrm{NaCl} 1.2 \mathrm{~g}$ 을 혼합한 시험관에 넣고 진탕(20 $\mathrm{min}$ 이상) 후 원심분리(2,000 $\mathrm{rpm}, 10 \mathrm{~min}$ )하였다. Butanol 층 $8 \mathrm{ml}$ 를 $50 \mathrm{ml}$ 시험관에 넣고 $0.1 \mathrm{~N}-\mathrm{HCl}$ 용액 $3 \mathrm{ml}, \mathrm{n}$-heptane $10 \mathrm{ml}$ 를 가하여 진탕 $(20 \mathrm{~min}$ 이상)후에 원심분리 $(2,000 \mathrm{rpm}, 10 \mathrm{~min})$ 하였다. 여기에서 얻어 진 수층 $2 \mathrm{ml}$ 에 $1 \mathrm{~N}-\mathrm{NaOH}$ 용액 $400 \mathrm{ul}$ 와 $1 \% O$-phthaldialdehyde (Sigma P-0657) 용액 $100 \mathrm{ul}$ 를 넣고 수욕상 $\left(37^{\circ} \mathrm{C}\right)$ 에서 $3 \mathrm{~min}$ 동안 반응시킨 다음, $3 \mathrm{~N}-\mathrm{HCl}$ 용액 $200 \mathrm{ul}$ 를 넣고 혼합 후에 $2 \mathrm{~min}$ 동안 방치하여 spectrofluorimeter ( $\lambda$ excitation= $360 \mathrm{~nm}, \lambda$ emission=440 nm)로 형광도를 측정하였다. 히스타 민 유리억제율(\%)은 다음과 같이 계산하였다.

억제율 $(\%)=\{(\mathrm{A}-\mathrm{B}) / \mathrm{A}\} \times 100$

- A: 약물을 부가하지 않았을 때의 histamine 양

- B: 약물을 부가하였을 때의 histamine 양

\section{Cytokine 분비량 측정}

장류 및 젓갈 분리 균체의 항염증 효과를 알아보기 위해 HMC-1 세포에 균주 추출물을 처리한 후 PMA와 A23187로 자극하여 유도된 cytokine (IL-6, TNF- $a$ 와 $\mathrm{IL}-8$ ) 분비량을 ELISA법으로 측정하였다. 96 well plate에 $\mathbb{L}-6, \mathrm{TNF}-a$ 와 $\mathbb{L}-8$ 의 monoclonal antibody를 넣어 $4^{\circ} \mathrm{C}$ 에서 하룻밤 코팅하였다. 0.05\% Tween20을 첨가한 phosphate buffer saline (PBST)로 
세척한 후 standard로 사용되는 recombinant IL-6, TNF-a, $\mathrm{IL}-8$ 과 시료를 각각 첨가하여 실온에서 $2 \mathrm{hr}$ 동안 반응시킨다. 세척 후 biotinylated anti-human $\mathbb{L}-6, \mathrm{TNF}-\mathrm{a}$ 와 $\mathrm{IL}-8$ 을 첨가하 여 실온에서 $2 \mathrm{hr}$ 동안 반응시킨 다음 avidin peroxidase를 넣어 $40 \mathrm{~min}$ 간 반응시킨 후 2,2'-azino- bis (3-ethylbenzthiazoline-6-sulfonic acid) (ABTS)를 첨가하여 $405 \mathrm{~nm}$ 에서 측정하 였다.

\section{결과 및 고찰}

\section{장류 및 젓갈 분리 균주의 $16 \mathrm{~S}$ rRNA 동정}

본 연구에서 장류 및 젓갈에서 분리되어 선별된 뒤 항알 레르기 효과를 알아보기 위해 사용된 균주인 J80과 G147균 주의 $16 \mathrm{~S}$ rRNA sequencing을 실시한 결과를 Table 1에 나 타내었다. J80은 Bacillus subtilis strain LB-01의 $16 \mathrm{~S}$ rRNA, partial sequence와 99\% 유사성을 나타내었으며 G147은 Bacillus sp. TPR06 16S rRNA patial sequence와 100\% 유사 성을 나타내었다. 이상의 실험결과로부터 장류 및 젓갈류에 서 분리한 균주를 Bacillus subtilis J80 및 G147로 명명하여 실험에 사용하였다.

장류 및 젓갈 유래 균체의 전처리에 따른 세포생존율 측정 MTT 시약은 살아있는 세포에서 formazan을 형성하는 데, 각기 다른 조건으로 전처리한 장류 및 젓갈 유래 균 체를 HMC-1 세포에 처리하고 MTT solution을 첨가하여 $37^{\circ} \mathrm{C}$ 에서 overnight한 후 HMC-1 세포에 MTT solution을 첨가하였을 때 보라색의 formazan을 형성하는 것이 관찰 되었다.

추출 방법을 달리한 장류 및 젓갈 유래 균체를 비만세포에 처리한 후 세포 생존율을 측정한 결과를 Fig. 2에 나타내었다. 전처리를 달리한 장류 및 젓갈 유래 균체를 처리한 실험군의

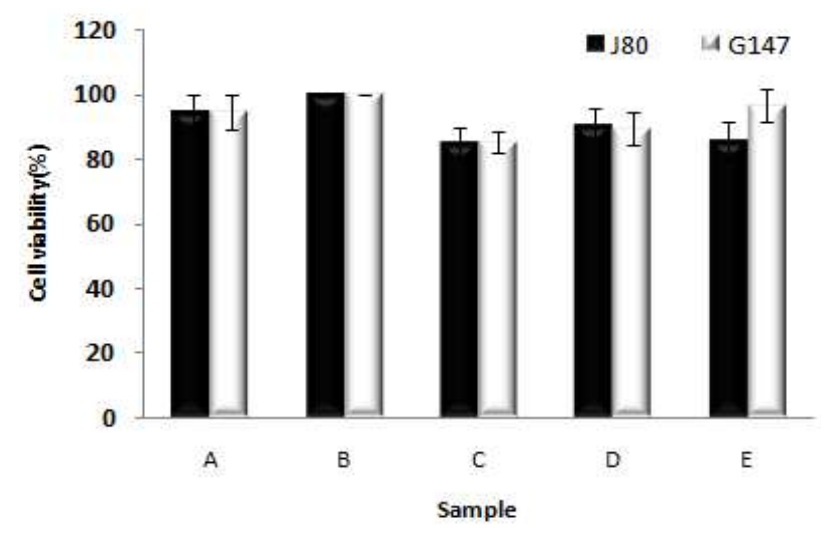

Fig. 2. Effects of bacterial extracts prepared by various methods on the viability of HMC- 1 cells. A: Stimulation (PMA, A23187), B: Control (Not treated), C: Sonication (20 min+PMA, A23187), D: Heating $\left(100^{\circ} \mathrm{C}, 30 \mathrm{~min}+\mathrm{PMA}\right.$, A23187), E: Autoclaving $\left(125^{\circ} \mathrm{C}, 15 \mathrm{~min}+\mathrm{PMA}, \mathrm{A} 23187\right)$

HMC-1의 생존율은 무처리군 B (Not treated)를 100\%로 환산 한 결과 약 $8697 \%$ 로 유의적 차이를 보이지 않아 장류 및 젓갈 유래 균체에 의한 세포 독성은 나타나지 않았다.

김 등[16]은 생쥐 면역세포인 EL-4 세포와 사람 면역세포인 Jurkat 세포에 가열한 김치 유산균을 처리하였을 때 세포 성장 에 영향을 주지 않는다고 보고하여 본 연구와 유사한 결과를 나타내었다.

장류 및 젓갈 유래 균체의 전처리에 따른 histamine 유리 억제효과

추출방법을 달리한 장류 및 젓갈 유래 균체를 $\mathrm{HMC}-1$ 에 처리한 후 histamine 유리 억제율을 측정한 결과를 Fig. 3에 나타내었다. Histamine 유리 억제율은 J80의 경우 sonication 한 C구가 $22.80 \%$ 였으며, $100^{\circ} \mathrm{C}$ 에서 $30 \mathrm{~min}$ 동안 가열한 $\mathrm{D}$ 구 는 $28.46 \%, 121^{\circ} \mathrm{C}$ 에서 15 min간 autoclaving 한 $\mathrm{E}$ 구는 $19.07 \%$

Table 1. The sequences of $16 \mathrm{~S}$ rRNA genes of bacteria (J80, G147) isolated from fermented soybean and Jeotgal

\begin{tabular}{ccccc}
\hline \multicolumn{2}{c}{ Query } & \multicolumn{2}{c}{ Subject } & \multicolumn{2}{c}{ Identities } \\
\hline Name & Length & Gene & Match & Percentage $(\%)$ \\
\hline J80 & 1414 & Bacillus sp. TPR06 16S rRNA gene, partial sequence & 1414 & 100 \\
G147 & 1441 & Bacillus subtilis 16S rRNA gene, partial sequence, strain: LB-01 & 1440 & 99 \\
\hline
\end{tabular}

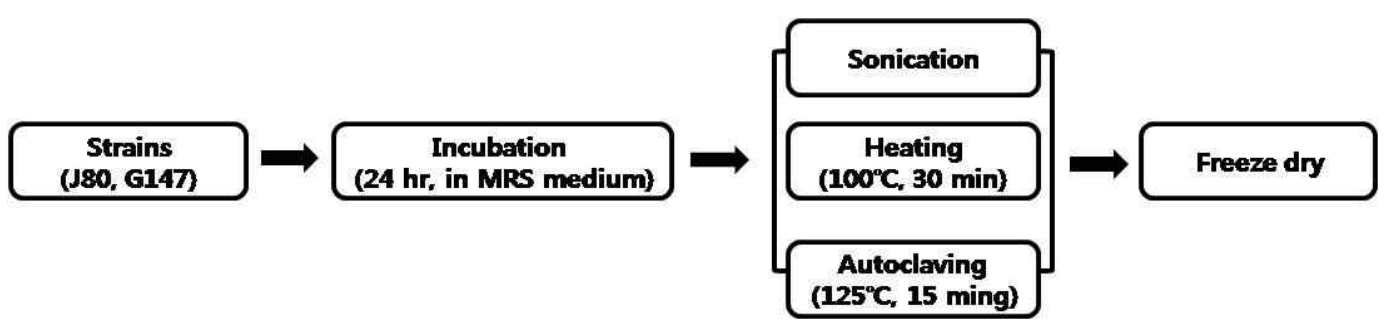

Fig. 1. Sample preparation for bacteria isolated from fermented soybean and Jeotgal. 


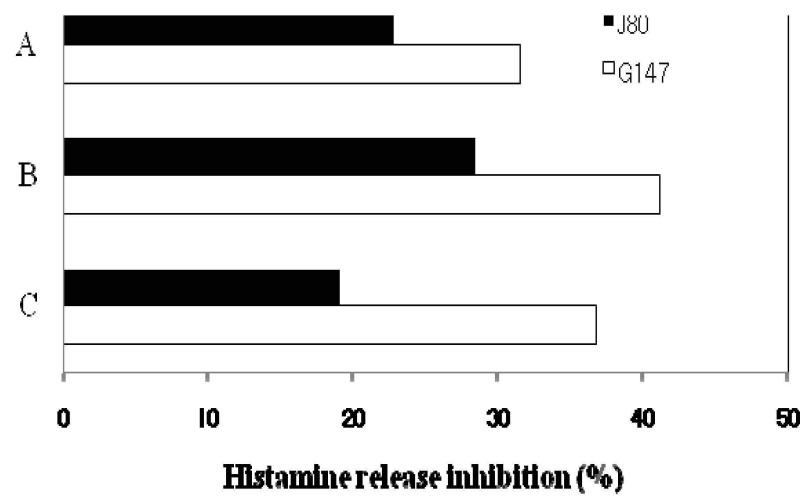

Fig. 3. Inhibitory effects of bacterial extracts on histamine release by HMC-1 cells. A: Sonication (20 min+PMA, A23187), B: Heating $\left(100^{\circ} \mathrm{C}, 30 \mathrm{~min}+\mathrm{PMA}, \mathrm{A} 23187\right), \mathrm{C}$ : Autoclaving $\left(125^{\circ} \mathrm{C}, 15 \mathrm{~min}+\mathrm{PMA}, \mathrm{A} 23187\right)$

로 나타났다. G147는 sonication한 C구가 $31.55 \%$ 였으며 $100^{\circ} \mathrm{C}$ 에서 $30 \mathrm{~min}$ 간 가열한 $\mathrm{D}$ 구는 $41.14 \%, 121^{\circ} \mathrm{C}$ 에서 $15 \mathrm{~min}$ 동안 autoclaving 한 E구는 $36.69 \%$ 의 억제효과를 보였다.

위 결과로 미루어보아 장류 및 젓갈 유래 균체는 $100^{\circ} \mathrm{C}$ 에서 $30 \mathrm{~min}$ 동안 가열처리하는 것이 $\mathrm{J} 80, \mathrm{G} 147$ 각각 $28.46 \%$, $41.14 \%$ 로 histamine 유리 억제효과가 가장 높은 것으로 관찰 되었다. 윤[37]은 김치에서 분리한 유산균을 가열하여 흰쥐의 비만세포주인 RBL-2H3에 처리하였을 때 histamine 분비를 억 제한다고 보고하여 본 연구와 유사한 경향을 보였다.

장류 및 젓갈 유래 균체의 전처리에 따른 IL-8 유리 억제효과 추출방법을 달리한 장류 및 젓갈 유래 균체를 비만세포에 처리하여 PMA와 A23187로 자극하였을 때 $\mathrm{IL}-8$ 유리량을 측 정하여 Fig. 4에 나타내었다. J80의 경우, Sonication (C),

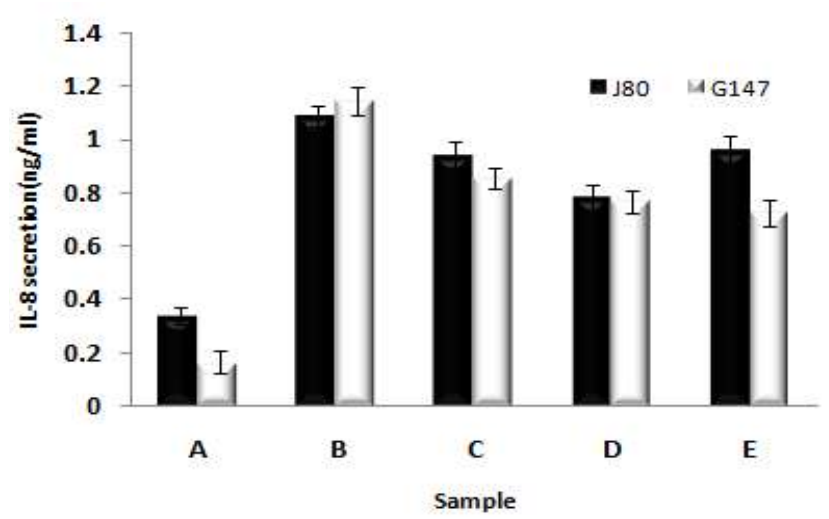

Fig. 4. Effects of bacterial extracts prepared by various methods on the PMA- and A23187-induced IL-8 secretion by HMC-1 cells. A: Control (Not treated), B: Stimulation (PMA, A23187), C: Sonication (20 min+PMA, A23187), D: Heating $\left(100^{\circ} \mathrm{C}, 30 \mathrm{~min}+\mathrm{PMA}, \mathrm{A} 23187\right), \mathrm{E}$ : Autoclaving $\left(125^{\circ} \mathrm{C}, 15 \mathrm{~min}+\mathrm{PMA}, \mathrm{A} 23187\right)$ heating (D), autoclaving (E)을 처리한 각각의 구에서 모두 $\mathrm{IL}-8$ 유리억제 효과를 나타내었으며 $100^{\circ} \mathrm{C}, 30 \mathrm{~min}$ 에서 처리 한 구에서 분비량이 $0.78 \mathrm{ng} / \mathrm{ml}$ 로 약 $28.45 \%$ 의 억제효과로 가장 높게 나타내었다. G147에서도 역시 sonication (C), heating (D), autoclaving (E)을 처리한 각각의 구에서 모두 $\mathrm{IL}-8$ 유리억제 효과를 나타내었으며 $125^{\circ} \mathrm{C}, 15 \mathrm{~min}$ 에서 처리 한 구에서 분비량이 $0.73 \mathrm{ng} / \mathrm{ml}$ 로 약 $36.52 \%$ 의 분비억제효 과로 가장 높게 나타내었다. 왕 등[35]은 태아 내장과 발효우 유에서 분리한 유산균들을 sonication 등으로 전처리해서 장 내세포주(Caco-2, HT-29 and HCT116)에 처리하였을 때, $\mathrm{IL}-8$ 의 분비를 억제시켜 염증반응을 억제한다고 보고하여 본 연구와 유사한 경향을 보였다.

장류 및 젓갈 유래 균체의 전처리에 따른 IL-6 분비 유리효과 처리방법을 달리한 장류 및 젓갈 유래 균체를 비만세포에 처리하여 PMA와 A23187로 자극하였을 때 $\mathrm{IL}-6$ 분비량을 측 정한 결과를 Fig. 5에 나타내었다. J80, G147의 장류 및 젓갈 유래 균체에서 무처리구(Not treated)인 대조구인 B의 분비량 인 $0.65 \mathrm{ng} / \mathrm{ml}$ (J80), $0.62 \mathrm{ng} / \mathrm{ml}$ (G147)보다 sonication (C), heating $(\mathrm{D})$, autoclaving $(\mathrm{E})$ 을 처리한 각각의 구에서 낮은 분 비량으로 $\mathrm{IL}-6$ 분비 억제효과가 나타났으며, J80에서는 $100^{\circ} \mathrm{C}$, $30 \mathrm{~min}$ 한 $\mathrm{D}$ 구의 분비량이 $0.40 \mathrm{ng} / \mathrm{ml}$ 으로 약 $38.46 \%$ 의 분비 억제효과로 가장 높게 나타났으며, G147 역시 $100^{\circ} \mathrm{C}, 30 \mathrm{~min}$ 한 $\mathrm{D}$ 구의 분비량이 $0.27 \mathrm{ng} / \mathrm{ml}$ 으로 $56.45 \%$ 로 가장 높은 분비 억제효과 보였다.

이 등[20]은 대장염 쥐 실험에서 유산균이 $\mathrm{IL}-6$ 분비를 억제 한다고 보고하였다. 또한 Miettinen 등[23]은 human peripheral blood mononuclear cells에서 10종의 유산균으로 cytokine 분비를 실험한 결과 glutaraldehyde로 fixing 한 유산균이

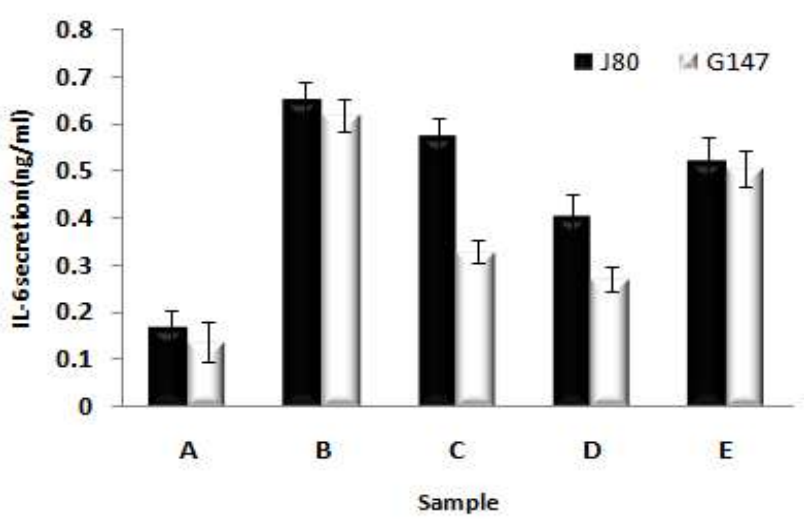

Fig. 5. Effects of bacterial extracts prepared by various methods on the PMA- and A23187-induced IL-6 secretion by HMC-1 cells. A: Control (Not treated), B: Stimulation (PMA, A23187), C: Sonication (20 min+PMA, A23187), D: Heating $\left(100^{\circ} \mathrm{C}, 30 \mathrm{~min}+\mathrm{PMA}, \mathrm{A} 23187\right), \mathrm{E}$ : Autoclaving $\left(125^{\circ} \mathrm{C}, 15 \mathrm{~min}+\mathrm{PMA}, \mathrm{A} 23187\right)$ 


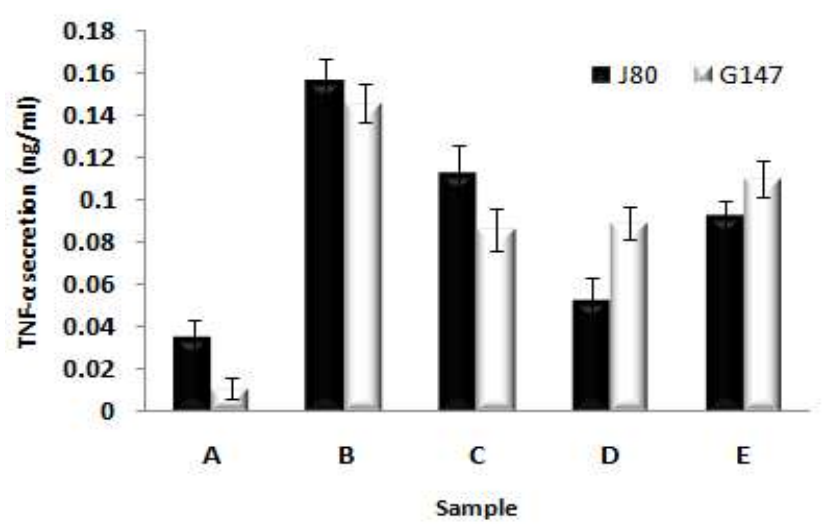

Fig. 6. Effects of bacterial extracts prepared by various methods on the PMA- and A23187-induced TNF-a secretion by HMC-1 cells. A: Control (Not treated), B: Stimulation (PMA, A23187), C: Sonication (20 min+PMA, A23187), D: Heating $\left(100^{\circ} \mathrm{C}, 30 \mathrm{~min}+\mathrm{PMA}, \mathrm{A} 23187\right), \mathrm{E}$ : Autoclaving $\left(125^{\circ} \mathrm{C}, 15 \mathrm{~min}+\mathrm{PMA}, \mathrm{A} 23187\right)$

IL-6 분비를 억제하는 것으로 보고하여 본 연구와 유사한 결과 를 보였다.

장류 및 젓갈 유래 균체의 추출방법에 따른 TNF-a 유리 억 제효과

추출방법을 달리한 장류 및 젓갈 유래 균체를 비만세포에 처리하여 PMA와 A23187로 자극하였을 때 TNF- $\mathrm{a}$ 분비량을 Fig. 6에 나타내었다.

IL-6와 마찬가지로 장류 및 젓갈 유래 균체 모두에서 대조구 $\mathrm{B}$ 의 분비량인 $0.156 \mathrm{ng} / \mathrm{ml}$ ( $\mathrm{J} 80), 0.146 \mathrm{ng} / \mathrm{ml}$ (G147)보다 낮 은 분비량으로 $\mathrm{TNF}-\mathrm{a}$ 분비 억제효과가 나타났다. 장류 유래 균주 $\mathrm{J} 80$ 의 경우 $100^{\circ} \mathrm{C}, 30 \mathrm{~min}$ 처리한 $\mathrm{D}$ 의 $\mathrm{TNF}-\mathrm{a}$ 분비량이 $0.052 \mathrm{ng} / \mathrm{ml}$ 으로 $66.67 \%$ 의 분비억제효과로 가장 높았으며, G147의 경우 sonication을 처리한 C구의 $\mathrm{TNF}-\mathrm{a}$ 분비량이 $0.086 \mathrm{ng} / \mathrm{ml}$ 으로 $41.1 \%$ 의 분비억제효과로 다른 구에 비해 높 은 억제효과를 나타내었다.

김 등[18]은 김치에서 분리한 유산균을 대식세포 활성화에 관한 연구에서 김치에서 분리한 유산균을 가열하여 대식세포 에 처리하였을 때 $\mathrm{TNF}-\mathrm{a}$ 분비가 증가하는 것으로 보고하였고, Miettinen 등[23]은 유산균의 종류에 따라 TNF-a 분비량은 차 이가 있지만 생균이 사균보다 TNF-a 분비량이 높다고 보고하 였다. 이러한 결과들은 균체 추출물의 처리 방법에 따라 염증 억제효과에 차이가 있음을 일부 확인해 주고 있다.

$$
\text { 감사의 글 }
$$

본 연구는 농림기술개발사업 위탁연구과제 연구비 지원(계 약번호: 306002-05)과 BK21 program 지원으로 수행되었기에 이에 감사드립니다.

\section{References}

1. Ahn, Y. M., J. B. Kim, Y. A. Kim, and O. N. Kim. 1990. Pharmacotherapy in allergic disorders (I). J. Korean Soc. Hosp. Pharm. 7, 112-120.

2. Arend, W. P. and J. M. Dayer. 1995. Inhibition of the production and effects of interleukin-1 and tumor necrosis factor alpha in rheumatoid arthritis. Arthritis Rheum. 38, 151-160.

3. Baggiolini, M. 2001. Chemokines in pathology and medicine. J. Intern. Med. 250, 91-104.

4. Butler, D. M., R. N. Maini, M. Feldmann, and F. M. Brennan. 1995. Modulation of proinflammatory cytokine release in rheumatoid synovial membrane cell cultures. Comparison of monoclonal anti TNF-alpha antibody with the interleukin-1 receptor antagonist. Eur. Cytokine Netw. 6, 225-230.

5. Chae, O., K. Shin, H. Chung, and T. Choe. 1998. Immunostimulation effects of mice fed with cell lysate of Lactobacillus plantarum isolated from Kimchi. Korean J. Biotechnol. Bioeng. 13, 424-430.

6. Chang, J. H., Y. Y. Shin, S. H. Kim, K. M. Chee, and S. K. Cha. 2005. Fibrinolytic and immunostimulating activities of Bacillus spp. strais isolated from Chungkuk-jang. Korean J. Food Sci. Technol. 37, 255-260.

7. Hong, S. Y. 2006. Characterization of biological response modifier produced by Bacillus licheniformis isolated from soybean paste. M.D. Thesis. Yonsei University. Seoul. Korea.

8. Hur, H. J., K. W. Lee, and H. J. Lee. 2004. Production of nitric oxide, tumor necrosis factor $-a$ and interleukin -6 by RAW264.7 macrophage cells treated with lactic acid bacteria isolated from Kimchi. Biofactors 21, 123-125.

9. Isolauri, E, P. Kirjavainen, E. Eerola, P. Kero, S. Salminen, and E. Isolauri. 2001. Probiotics in primary prevention of atopic disease: a randomised placebo-controlled trial. Lancet 50, 54-59.

10. Kang, K. O. 2006. Assessment of allergenicity of fermented dairy products by immunoassay. Korean J. Food Nutr. 19, 296-300.

11. Kang, O. H., H. S. Chae, J. H. Choi, H. J. Choi, J. H. Park, P. S. Park, S. H. Cho, G. H. Lee, H. Y. So, Y. K. Choo, O. H. Kweon, and D. Y. Kwon. 2006. Effects of the Schisandra fructus water extract no cytokine release from a human mast cell line. J. Med. Food 9, 480-486.

12. Kaizu, H., M. Sasaki, H. Nakajima, and Y. Suzuki. 1993. Effect of antioxidative lactic acid bacteria on rats fed a diet deficient in vitamin E. J. Dairy Sci. 76, 2493-2499.

13. Kato, I., K. Endo, and T. Yokokura. 1994. Effects of oral administration of Lactobacillus casei on antitumor responses induced by tumor resection in mice. Int. J. Immunopharmacol. $16,29-36$.

14. Kim, H. J. 2004. Antitumor effects of immune activity by cell wall extract of lactic acid bacteria. M.D. Thesis. Sungkyunkwan University, Seoul, Korea.

15. Kim, J. W. 2008. Inhibitory Effects of Lactic Acid Bacteria Extracts Isolated from Kimchi by Extraction Methods on the 
Mast Cell - Mediated Inflammatory Response. M.D. Thesis. Gyeongsang University, Jinju, Korea.

16. Kim, M. S., W. K. Lim, J. G. Cha, N. H. An, S. J. Yoo, J. H. Park, H. M. Kim, and Y. M. Lee. 2001. The activation of PI3-K and PKC 3 in PMA-induced differentiation of HL-60 cells. Cancer Lett. 171, 79-85.

17. Kim, M. S., J. M. Yi, S. H. Kim, S. H. Hong, and H. M. Kim. 2004. Madimadi, Korean fork medicine, blocks TNF-a, $\mathrm{IL}-1 \beta$, and $\mathrm{IL}-8$ production by activated human immune cells. Cytokine 25, 179-186.

18. Kim, S. K. 2008. Different modes of immunostimulation induced by lactic acid bacteria isolated from kimchi in the murine immune system. Seoul National University Press.

19. Lee, C. Y. 1989. Korean soy seasonings and culture. Food Sci. Ind. 22, 3-7.

20. Lee, H. S., S. Y. Han, E. A. Bae, C. S. Huh, Y. T. Ahn, J. H. Lee, and D. H. Kim. 2008. Lactic acid bacteria inhibit proinflammatory cytokine expression and bacterial glycosaminoglycan degradation activity in dextran sulfate so- $^{-}$ dium-induced colitic mice. Int. Immunopharmacol. 8, 574-580.

21. Lee, H. Y., Y. Lee, J. H. Park, S. H. Seok, S. A. Cho, M. W. Baek, D. J. Kim, and J. H. Park. 1993. Effect of fprobiotic lactic acid bacteria isolates in Korea in cutaneous hypersensitivity rats. Korean J. Lab. Ani. Sci. 19, 117-119.

22. Miescher, S. M. and M. Vogel. 2002. Molecular aspects of allergy. Mol. Aspects Med. 23, 413-462.

23. Miettinen, M., J. Vuopio-Varkila, and K. Vakila. 1996. Production of human tumor necrosis factor alpha, ingerleukin-6 and interleukin-10 is induced by lactic acid bacteria. Infect. Immun. 64, 5403-5405.

24. Mukaida, N. 2000. Interleukin-8: an expanding universe beyond neutrophil chemotaxis and activation. Intern. $J$. Hematol. 72, 391-398.

25. Nilsson, G., J. H. Butterfield, K. Nilsson, and A. Siegbahn. 1994. Stem cell factor is a chemotactic factor for human mast cells. J. Immunol. 153, 3717-3723.

26. Nomoto, K., S. Miake, S. Hashimoto, T. Yokokura, M. Mutai, M. Yoshikai, and K. Nomoto. 1985. Augmentation of host resistance to Listeria monocytenens infection by Lactobacillus casei. J. Clin. Lac. Immunol. 17, 91-97.

27. Park, B. J., K. S. Jang, D. H. Kim, H. S. Yook, and M. W. Byun. 2002 Changes of microbiological and physicochemical characteristics of Doenjang prepared with low salt content and gamma irradiation. Korean J. Food Sci. Technol. 34, 79-84.

28. Park, S. Y., Y. T. Ko, H. K. Jung, J. O. Yang, H. S. Chung, Y. B. Kim, and G. E. Ji. 1996. Effect of various lactic acid bacteria on the serum cholesterol levels in rats and resistance to acid, bile, and antibiotics. Korean J. Appl. Microbiol. Biotechnol. 24, 304-310.

29. Petersen, L. J., H. Mosbech, and P. S. Skov. 1996. Allergen-induced histamine release in intact human skin in vivo assessed by skin microdialysis technique: characterization of factors influencing histamine releasability. J. Allergy Clin. Immunol. 97, 672-679.

30. Roitt, I., J. Brostoff, and D. Male. 2001. Immunology 6th eds. Mosby 323-383.

31. Seo, U. K., J. I. Lee, J. H. Park, and Y. K. Park. 2008. The Ethylacetate Extract of North Kangwhal (Ostericum koreanum) Attenuates the Inflammatory Responses in PMA/A23187-stimulated Mast Cells. Korean J. Herbol. 23, 81-89.

32. Shida, K., K. Makino, A. Morishita, K. Takamizawa, S. Hachimura, A. Ametani, T. Sato, Y. Kumagai, S. Habu, and S. Kaminogawa. 1998. Lactobacillus casei inhibits antigen-induced $\operatorname{IgE}$ secretion through regulation of cytokine production in murine splenocyte cultures. Int. Arch. Allergy Immunol. 115, 278-287.

33. Shin, K., O. Chae, I. Park, S. Hong, and T. Choe. 1998. Antitumor effects of mice fed with cell lysate of Lactobacillus plantarum isolated from kimchi. Korean J. Biotechnol. Bioeng. 13, 357-363.

34. Shore, P. A., A. Burkhalter, and V. H. Cohn. 1959. A method for the fluorometric assay of histamine in tissue. J. Pharmar. Exp. Ther. 127, 182-186.

35. Wang, S., W. L. Chow, and Y. K. Lee. 2008. Infant international Enterrococcus faecalis down-regulates inflammatory responses in human intestinal cell lines. World J. Gastroenterol. 14, 1067-1076.

36. Wedemeyer J, M. Tsai, and S. J. Galli. 2000. Roles of mast cells and basophils in innate and acquired immunity. Curr. Opin. Immunol. 12, 624-631.

37. Youn, M. S. 2006. Effect of Lactobacillus sakei probio 65 Kimchi on immune function and atopic dermatitis. M.D. Thesis. Dankook University, Seoul, Korea. 


\section{초록 : 장류 및 젓갈 분리 균주 추출물의 비만세포 매개 항염증효과}

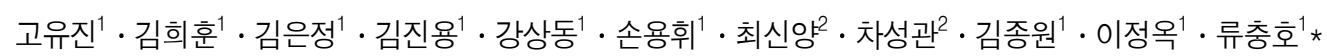
(경상대학교 응용생명과학부(BK 21 프로그램) · 농업생명과학연구원, ${ }^{2}$ 한국식품개발연구원)

본 연구에서 장류 및 젓갈 유래 균체를 각각 sonication, $100^{\circ} \mathrm{C}$ 에서 $30 \mathrm{~min}, 125^{\circ} \mathrm{C}$ 에서 $15 \mathrm{~min}$ 의 조건으로 추출 하여 $\mathrm{HMC}-1$ 에 처리하였을 때, 이 추출방법에 따른 $\mathrm{HMC}-1$ 매개 염증반응 억제효과를 조사하였다. 추출방법을 달리하여 추출한 장류 및 젓갈 유래 균체 J80, G147이 HMC-1생존율에 미치는 영향은 대조구 B (Not treated)와 비교하였을 때 86 96\%로 유의적 차이를 보이지 않아 장류 및 젓갈 유래 균체에 의한 세포 독성은 나타나지 않았 다. 장류 및 젓갈 유래 균체의 모든 전처리구에서 histamine 유리 억제효과를 나타내었으며 특히, $100^{\circ} \mathrm{C}$ 에서 30 $\min$ 동안 가열하였을 때 histamine 억제율이 J80에서 $28.86 \%$, G147에서 $41.14 \%$ 으로 가장 높게 나타냈다. IL-8 분비량은 $\mathrm{J} 80, \mathrm{G} 147$ 의 모든 전처리구에서 $\mathrm{IL}-8$ 분비억제효과가 나타났으며, $\mathrm{J} 80$ 의 경우 $100^{\circ} \mathrm{C}, 30 \mathrm{~min}$ 에서 처리한 구에서 분비량이 $0.78 \mathrm{ng} / \mathrm{ml}$ 로 대조구 B (Not treated)에 비하여 약 $28.45 \%$ 의 분비억제효과로 가장 높게 나타내었 다. G147의 경우 $125^{\circ} \mathrm{C}, 15 \mathrm{~min}$ 에서 처리한 구에서 분비량이 $0.73 \mathrm{ng} / \mathrm{ml}$ 로 약 $36.52 \%$ 의 분비억제효과로 가장 높게 나타내었다. IL-6 분비량을 측정한 결과 J80, G147의 모든 실험구에서 IL-6 분비억제효과가 나타났으며, J80에 서는 $100^{\circ} \mathrm{C}, 30 \mathrm{~min}$ 한 $\mathrm{D}$ 구의 분비량이 $0.40 \mathrm{ng} / \mathrm{ml}$ 으로 대조구 B (Not treated)에 비하여 약 $38.46 \%$ 의 분비억제효 과로 가장 높았으며, G147 역시 $100^{\circ} \mathrm{C}, 30 \mathrm{~min}$ 동안 처리한 $\mathrm{D}$ 구의 분비량이 $0.27 \mathrm{ng} / \mathrm{ml}$ 으로 대조구 B (Not treated)에 비하여 $56.45 \%$ 의 분비억제효과로 가장 높게 나타냈다. TNF- $a$ 분비량 역시 $\mathrm{IL}-6$ 와 마찬가지로 J80, G147에서 대조구 B보다 낮은 분비량으로 $\mathrm{TNF}-\mathrm{a}$ 분비 억제효과가 나타났으며 J80의 경우 $100^{\circ} \mathrm{C}, 30 \mathrm{~min}$ 처리한 $\mathrm{D}$ 의 TNF-a 분비량이 $0.052 \mathrm{ng} / \mathrm{ml}$ 으로 $66.67 \%$ 의 분비억제효과로 가장 높았으며, G147의 경우 sonication을 처리한 C구의 $\mathrm{TNF}-\mathrm{a}$ 분비량이 $0.086 \mathrm{ng} / \mathrm{ml}$ 으로 $41.1 \%$ 의 분비억제효과로 다른 구에 비해 높은 억제효과를 나타내었다. 위의 결과를 통해서 장류 및 젓갈 유래 균체의 3 가지 전처리 방법 중 $100^{\circ} \mathrm{C}, 30 \mathrm{~min}$ 처리 시 염증 반응 억제 효과가 가장 높을 것으로 예상된다. 결과를 미루어보아 장류를 섭취하는 대표적인 방법인 가열하여 찌개로 조리과정 중 장류 및 젓갈 속의 균체가 열에 가열되면서 염증억제효과 높일 수 있는 가장 좋은 조리 방법으로 사료되며, 이는 대중들이 가장 가깝게 염증반응 억제효과를 볼 수 있는 식품일 것이다. 또한 염장처리과정만을 거친 젓갈을 섭취 하는 것보다 열처리과정을 거친 젓갈을 섭취할 경우 염증억제효과를 더 높일 수 있을 것으로 예상된다. 